\title{
Bureaucracy And Charities: The Economics Of Private Voluntary Aid
}

Abdiweli M. Ali, (Email: amali@niagara.edu), Niagara University

\section{INTRODUCTION}

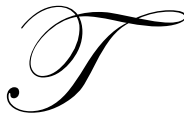

he non-profit sector usually called the third sector is growing due to the increase in demand for the kind of services that these organizations traditionally provided, such as relief aid, daycare, education and hospital services. Governments also increased support for them because the services they delivered are collective in nature. They yield benefits that are not restricted to the donors or clients.

Non profit firms differ fundamentally from for profit firms in that non-profits are not by their definition allowed to distribute profits to any owner or stockholder. The US Congress exempted tax from non-profit organizations (NPOs) on the basis of public welfare theory; the theory being that NPOs perform services that the government would otherwise have to provide in their absence; therefore, any loss of revenue resulting from that tax exemptions is more than offset by shifting the financial burden for providing those services from the federal treasury to tax exempt organizations.

Some cynics would say that NPOs exist and expand because they enjoy favorable tax exemptions (Bennett and Dilorenzo 1989). Although most of the non-profit groups are exempt from corporate income tax, some non-profit firms like AAA automobile clubs and Blue-Cross Blue-Shields have the same tax status as for profit firms. Others also argue that governments grant exemptions to have some control over the activities that these organizations are involved.

Tax exemptions for non-profit service organizations make sense theoretically since they provide a benefit the state does not adequately perform and hence they lessen the burden on the public purse. Tax exemptions also allow the government to encourage certain activities of a public nature without actually accepting responsibility for themespecially when there is no public consensus that the state should take these functions (e.g. support for religious education). This paper tries to present the economic rationale of non-profit firms. The rest of the paper is organized as follows: section 2 presents non-profit organization in an international perspective. Section 3 highlights the economic theory of non-profits. Section 4 develops a limited managerial discretionary model of non-profit firms. Section 5 is a brief discussion of the politics of donations, while section 6 concludes and summarizes the main points of the paper.

\section{NPO'S IN INTERNATIONAL PERSPECTIVE}

According to Adam Smith, the secular exercise of charity was an expression of humanitarian sympathy, involving both a feeling for other individuals and an ability to picture oneself in their place. Hence, non-profit service institutions in the early modern period came to be seen as expression of humanitarian concern as well as a means to maintain the social system. They headed off or relieved social tensions in society so as to basically preserve a differentiation among economic groups and thus maintain the status quo. Non-profit service organizations enhanced societal stability by serving as instruments of social control.

The agendas of many American non-profits don't always coincide exactly with those of their private and governmental donors. Although the primary motive of many private sponsors is relief-oriented and most responsive to addressing short term crises (hunger, sickness, homelessness, flood and droughts), the goals of private voluntary organizations (PVOs) are somewhat different and geared to developmental objectives such as income generation, training, education, public health, and community development. A principal-agent problem arises because PVOs are interested in prolonging and maintaining their activities while the short term crises are temporary in nature (Eastley and O'Hara 1983a). 
Many non-profits are also coming to define their development objectives in political rather than economic terms. A considerable part of the American non-profit sector that engage in overseas aid is clearly promoting more than charitable goals abroad that are not often upper most in the minds of its private and governmental donors. They also support groups in the third world countries and advocate programs that are different from and sometimes opposed to strategies endorsed by government policymakers in their home countries. An example is the American PVOs currently working in Cuba.

Some non-profits also contributed to the stability of oppressive governments and serve the interest of those in power. The social services they provided to low income sectors relieved the respective governments from taking care of groups not part of their support base. Moreover, PVOs are staffed by middle class opponents of the regime. They thus channel the energies of the dissidents into constructive gap-filling functions that at least indirectly enhanced regime stability. If such dissidents did not have the outlets, they might have tempted to search for more radical and violent modes of expressing their dissatisfaction with regime policies. They serve some of the immediate interests of governments and businesses, even in situations when they are pursuing policies in clear opposition to the established order (caring for the persecuted for authoritarian regimes; working in areas favorable to guerillas, or serving the need of the poor who are disenchanted with public bureaucracies in one party states). They help placate working class sectors and give them a sense of hope that the system is malleable and responsive to their needs.

\title{
THE ECONOMIC THEORY OF THE NON-PROFITS
}

\author{
Non-Profits Exist Because Of The Following Reasons:
}

\section{Asymmetric Information}

This phenomenon arises when the seller has access to more information than the buyer. If the donations are made to a for-profit firm, owners and managers will behave so as to maximize profits. There is an incentive to spend as little as possible if the risk of being caught is small. For-profit firms will take advantage of their superior information relative to consumers and donors who cannot enforce contracts economically. When monitoring is costly for consumers, the non-profit firm is often more efficient. They are more trustworthy because they have different incentives and non-profits develop where trustworthiness is important.

Henry Hausmann (1980) has argued that the core purpose of the non-profit sector is to operate in those areas where consumers (buyers of goods and services, and contributors to charity) have no way to police producers by ordinary contractual devices - e.g., if the possibility of cheating to increase profits is greater due to the absence of effective market competition for a certain commodity, or if the service is to be delivered to a far-off place so that donors don't see the beneficiaries.

In these situations donors may be willing to trust non-profits, because profit maximizing managers would have an incentive to downgrade quality, but this incentive may be weakened in non-profits by the non-distribution constraint. The basic idea is that if managers cannot benefit financially by receiving profits they will be less likely to cheat consumers, therefore non-profits are more trustworthy. While the non-distribution constraint makes non-profits more trustworthy and gives some protection to consumers, it also makes them less efficient. If no one has a property right in the residual, no one has an incentive to keep the organization free from waste. So, if the monitoring cost is not exorbitant, the greater efficiency of the for-profit may be preferred to the trustworthiness of the non-profits.

\section{Thin Markets}

Burton Weisbrod (1978) stressed the comparative advantage of non-profit organizations vis-à-vis government in performing certain needed public functions. He believes that non-profits support collective consumption goods for which there is not yet a demand from the majority of the citizens or for which a majority of citizens are prepared to pay in taxation only in amounts that a minority considers inadequate. In these markets the demand for the service is so small that no commercial firm could make a profit selling it and because of the subsidies which artificially lower costs, NPOs can serve such a market. They can produce goods with lower cost than 
government or private for-profit firms, especially for labor. They benefit from voluntary donations of time as well as money. The non-profit firms have also the opportunity to produce slightly different consumer tastes due to religious, cultural, geographical and ethnic differences.

\section{Unsatisfied Demand}

The decision of which public goods are provided, is determined through politics. Some people will desire more than the amount chosen by the median voter, but the government is limited by the democratic constraint that permits it to support only what it believes the majority wants or would approve. Those unsatisfied with the level of public goods provision can resort to the NPOs. The under-satisfied demand for collective type goods is a governmental failure analogous to private market failures. That is, the combined willingness of a part of the population to pay for some additional collective goods exceed the incremental cost of providing them and yet the government, responding to majoritarian interest does not provide them.

Non-profits are substitutes for government in providing quasi-public goods. They can charge fee for services, so the government's share of total cost is reduced when responsibility is delegated to them. More can be served for the same public expenditure. ${ }^{1}$

\section{A LIMITED MANAGERIAL DISCRETIONARY MODEL OF NON-PROFITS}

Non-profits are believed to be like governmental organizations, in being restricted in the use of any surplus they generate. In reality, non-profits are not subject to all the constraints that are commonly believed to exist. Most notably they are not restricted in the amount of profits they may make, only on what they may do with the profitsessentially being constrained to use them to purchase more resources for the organization. Neither are non-profits prohibited from engaging in activities, commercial or other, that are totally unrelated to the purpose of which they were granted exemption from the corporate income tax.

Whether in the for-profit or non-profit sector, individuals can be expected to try to enhance their own selfinterest. Since managers of non-profit organizations cannot enhance their own self-interest by increasing profits, they are likely to seek alternative goals, such as the prestige associated with having large staff and office emoluments. Managers of many NPOs enrich themselves at the expense of their organization and their patrons. They may receive excessive salaries, personal services and amenities paid out of organization funds. Also businesses owned by the managers may receive generous contracts for goods and services, and friends and relatives might be given patronage jobs.

There is also a huge incentive to expand the operations of the non-governmental organizations (NGOs). Excess revenues are held internally (is not distributed to shareholders) and may be used by management for perquisites. Thus, the growth-oriented appetite of bureaucrats are encouraged by non-distributive characteristics of the NGOs. ${ }^{2}$ For profits firms are also expansionary when there is a separation of management and control, but competitive markets limit such behavior.

\section{The Model}

The managerial discretionary model which arises from the idea that the manager of a non-profit organization operates so as to maximize his utility subject to a zero profit distribution can explain the behavior of non-profit organizations.

Let us assume that a non-profit firm supports both education and research. In this firm, the utility of the manager is a positive function of the amount of research and education provided.

\footnotetext{
${ }^{1}$ See Rose-Ackerman (1986) for a detailed explanation of the theory of "unsatisfied demand."

${ }^{2}$ See Niskanen (1971) for a detailed analysis of the growth of bureaucracy.
} 
$\mathrm{U}_{\mathrm{m}}=\mathrm{f}(\mathrm{R}, \mathrm{E}), \delta \mathrm{U} / \delta \mathrm{R}>0, \delta \mathrm{U} / \delta \mathrm{E}>0$, where $\mathrm{R}=$ research and $\mathrm{E}=$ education.

Let us assume that a non-profit firm produces a public good like education. As the following diagram shows, the manager will choose levels of research and education $\left(\mathrm{E}^{*}, \mathrm{R}^{*}\right)$ that maximize his utility, given the constraint that his chosen bundle must lie somewhere on the zero-profit line. Non-profit managers enjoy greater discretion than their counterparts in the for-profit sector. They can use their discretion to influence the selection of inputs and the choice of output. Employees and staff of non-profit institutions have also a stake in retaining the non-profit firm which may offer them greater control, financial remuneration, and protection from competition than would for-profit firms.
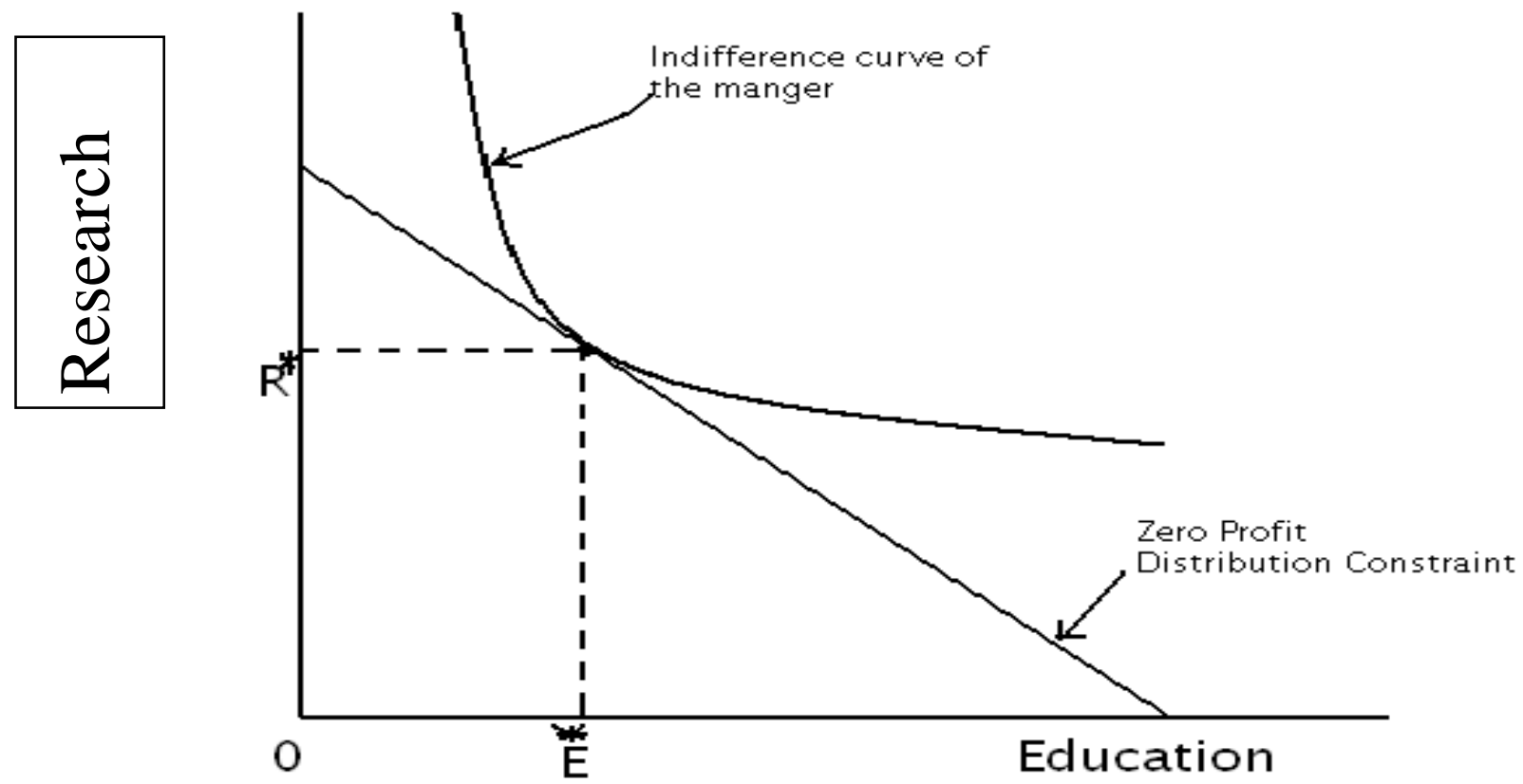

\section{A Limited Managerial Discretionary Model Of Non-Profits With A Public Choice Twist}

In this model, the firm provides the product by using donations from individuals or from the government. The manager derives utility from the perks associated with the provision of the good but not from the good itself.

$\mathrm{U}_{\mathrm{m}}=\mathrm{u}[\mathrm{P}(\mathrm{E}), \mathrm{E}], \delta \mathrm{U} / \delta \mathrm{P}>0, \delta \mathrm{U} / \delta \mathrm{E}<0$, and $\mathrm{P}=\mathrm{f}(\mathrm{E})$, where $\mathrm{P}$ is the amount of perks which depends on the amount of education (E) provided.

$\delta \mathrm{U} / \delta \mathrm{E}=\delta \mathrm{U} / \delta \mathrm{P} * \delta \mathrm{P} / \delta \mathrm{E}+\delta \mathrm{U} / \delta \mathrm{E}=0$, or $\delta \mathrm{U} / \delta \mathrm{P} * \delta \mathrm{P} / \delta \mathrm{E}=\delta \mathrm{U} / \delta \mathrm{E}$. This is the manger's first-order condition. The element in the left-side of the equation is the marginal benefit of perks associated with providing education. The elements on the right hand side of the equation is the opportunity cost of providing education.

Let us now look at the utility function of the donor. $\mathrm{U}_{\mathrm{d}}=\mathrm{u}[\mathrm{E}(\mathrm{C}), \mathrm{C}], \delta \mathrm{U} / \delta \mathrm{E}>0, \delta \mathrm{U} / \delta \mathrm{C}<0$; where $\mathrm{U}_{\mathrm{d}}$ is the utility of donors and $\mathrm{C}$ is the amount of contributions given. The donors derive utility from education; and the amount of education is also a function of the contributions.

$\delta \mathrm{U} / \delta \mathrm{C}=\delta \mathrm{U} / \delta \mathrm{E} * \delta \mathrm{E} / \delta \mathrm{C}+\delta \mathrm{U} / \delta \mathrm{C}=0$, or $\delta \mathrm{U} / \delta \mathrm{E} * \delta \mathrm{E} / \delta \mathrm{C}=\delta \mathrm{U} / \delta \mathrm{C}$. This is the donor's first-order condition. This equation characterizes the equilibrium of the donor at where the marginal benefit of donating is equal to the marginal cost of donations. 
The implicit function theorem allows that $\mathrm{E}^{*}=\mathrm{e}(\mathrm{C})$. This is the reply function of the manager and $\mathrm{C}^{*}=\mathrm{c}(\mathrm{E})$, which is the reaction function of the donors. At the Nash equilibrium: $E^{* *}=e\left(C^{*}\right)$; and $C^{*}=c\left(E^{* * *}\right)$. As the diagaram below indicates, the utility-maximizing level of education is $\mathrm{E}^{* *}$, and the utility-maximizing level of contributions associated with this level of education is $\mathrm{C}^{* *}$. There is also a diminishing marginal utility associated with the provision of education. As the diagram below indicates the maximum amount of education provided by the non-profit firms is $\mathrm{E}^{* *}$. Initially, the amount of education provided increases with the amount of contributions from donors, however, after a certain level the marginal utility of an additional unit of education becomes zero.

Likewise, the manager receives no additional contributions from donors beyond the utility-maximizing level of education. The maximum amount of contributions from donor will be $\mathrm{C}^{* *}$ regardless of the amount of education he provides. Therefore, the $\mathrm{E}=\mathrm{e}(\mathrm{C})$ line becomes vertical and backward-pending after $\mathrm{E}^{* *}$. Similarly, the $\mathrm{C}=\mathrm{c}(\mathrm{E})$ becomes horizontal after the equilibrium level of education.

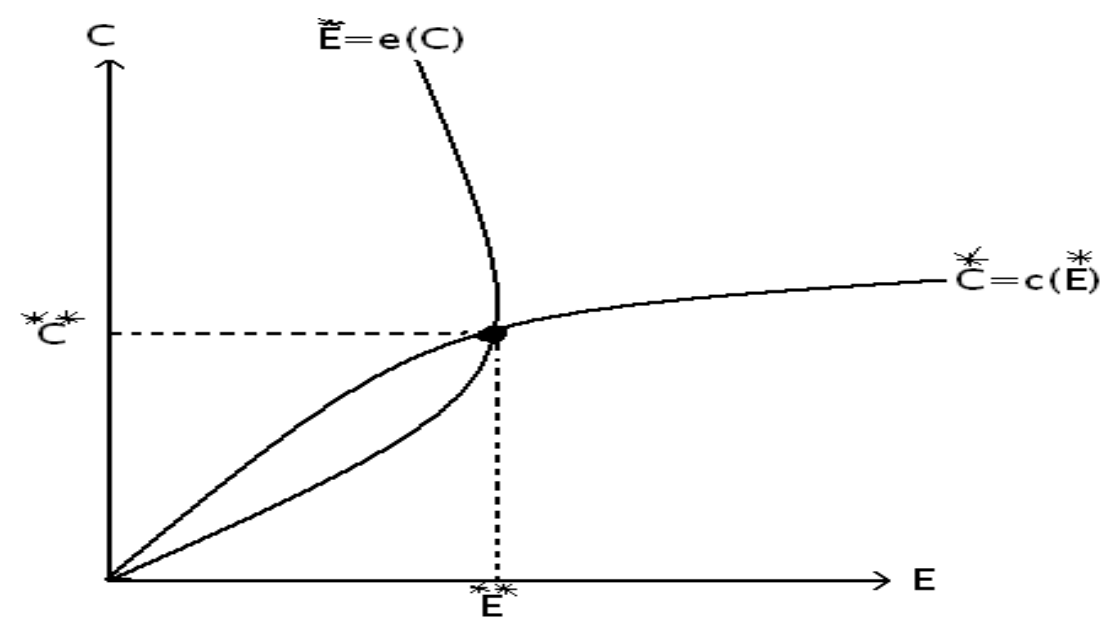

\section{THE POLITICS OF DONATIONS AND THE FREE-RIDER PROBLEM}

The motivation for charitable giving is rooted not in altruism but in self-interest. Enlightened individuals explicitly recognize that some small sacrifice might be necessary if the ultimate self-interest is adequately to be served. For example, that corporations make contributions simply reflects the fact that corporate management recognize that the long-term welfare of the business depends, among other things on the health of the environment of which they are part. Many of the charitably wealthy are also involved in politics. The giving practices of most donors are related to their political beliefs and involvement. They give so as to grow and serve them better in the future.

If the private non-profit institutions are to correct governmental failures that created unsatisfied demand; they must overcome the free-rider problem. Non-profits have some instruments to deal with this problem: social pressure and subsidy. Many people pay non-profits because they have been socialized to believe that it is desirable and the right thing to do.

Donations are also tax deductible. This deductibility stimulates giving because it reduces after-tax cost to the donor. Tax-subsidy policies encourage high demanders to reveal their true preferences. Whenever donations are deducted from taxes, tax revenue is reduced. In effect, taxpayers will reveal their greater willingness to pay for the collective good by donating. The subsidy is understandable insofar as these are taxpayers with lower but positive demands for collective goods; they would benefit if the high demanders increase their contributions. Tax subsidies therefore represent, in effect, contributions from low demanders to stimulate the high demanders to contribute. 
When governments delegate the production of some public goods rather than producing itself, NPOs create or encourage political pressure on policymakers to provide the services that these organizations are engaged in producing it. ${ }^{3}$ One of the ways this comes about is overemphasizing the importance of their functions through media outlets. CARE, an American voluntary organization erroneously claimed that 1.5 million refuges lived in Somalia, while the actual number was one-third of that number. ${ }^{4}$ The politicians respond to these pressures positively, because these organizations can easily charge fees for services that reduce the government's share of the total cost and this in turn will reduce the pressure on politicians to deliver.

\section{CONCLUSION}

This paper tries to shed light on the economics of non-profit firms. It presents a limited managerial discretionary model of non-profits to indicate that the functions of the non-profits are not devoid of self-interest. The model shows that non-profits are not that different than for-profit firm except that they are constrained by the zeroprofit condition associated with non-profits. Nevertheless, the managers of non-profit are self-interested utilitymaximizers like their counterparts in for-profit firms. The limited role that they can play is clear from the analysis above. If non-profit organizations perform a useful role, they must provide outputs that cannot be provided profitably by private enterprises. It must be the case that the lure of profit doesn't lead to a socially efficient allocation of resources when there are socially valuable forms of outputs that are not rewarded financially----either because they are costly to buyers to evaluate or because they go to persons with little ability to pay.

Non-profit organizations operate under different rules and regulations than private, profit seeking firms. They are granted special privileges that give them significant advantages in the market place. They are exempt from federal, state and local taxation and from many regulations; and they often have preferences in obtaining government grants and contracts. These exemptions and privileges reduce the production costs for non-profits and give them an edge over their private competitors. For profit firms are penalized even further to the extent that they have borne the cost of the subsidies in the form of higher taxes. In many cases, existing profit seeking firms have been driven from the market or have suffered economic losses and new firms have been discouraged from entering markets in which nonprofits operate

\section{REFERENCES}

1. Becker, Gary, 1983, A Theory of Competition Among Pressure Groups for Political Influence, Quarterly Journal of Economics, Vol. 98, pp. 371-400.

2. Bennett, James, and Thomas Dilorenzo, 1989, Unfair Competition: The Profits of the Non-profits, Hamilton Press: Lanham, MD.

3. Eastley, P, and M. O'Hara, 1983a, The Economics of Non-profit Firms, Bell Journal of Economics, Vol. 14, pp. 531-538.

4. Hancock, Graham, 1989, Lords of Poverty, The Atlantic Monthly Press: New York, NY.

5. Hausmann, Henry, 1980, The Role of Non-profit Enterprises, Yale Law Journal, Vol. 89 (5), pp. 835-901.

6. Niskanen, William, 1971, Bureaucracy and Representative Government, Aldine-Atherton: Chicago, IL.

7. Rose-Ackerman, Susan, 1982, Unfair Competition and Corporate Income Taxation, Stanford Law Review, Vol. 34, pp. 1016-1039.

8. $\quad$---------------, 1986, The Economics of Non-profit Institutions: Studies in Structure and Policy, Oxford University Press: Oxford, UK.

9. Smith, Brian H., 1990, More Than Altruism: The Politics of Private Foreign Aid, Princeton University Press: Princeton, NJ.

10. Weisbrod, Burton, 1978, The Voluntary Non-profit Sector: An Economic Analysis, Lexington Books, D.C Heath: Lexington, MA.

\footnotetext{
${ }^{3}$ See Gary Becker (1983) for a full description of the rent seeking activity of political pressure groups.

${ }^{4}$ For this anecdote and more, see Hancock (1989).
} 